\title{
EFFECTS OF FAST NEUTRON IRRADIATION ON THE PERFORMANCE CHARACTERISTICS OF REACTOR-GRADE THERMOCOUPLES
}

N. C. Hoitink, R. C. Weddle and D. C. Thompson

June 1970

\section{AEC RESEARCH \& DEVELOPMENT REPORT}

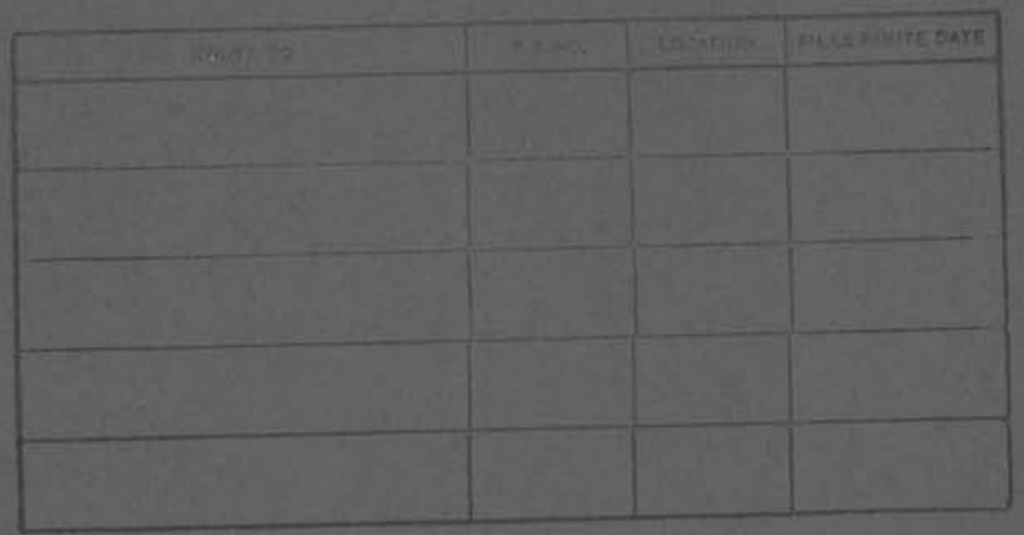




\section{LEGAL NOTICE}

This report was prepared as an account of Government sponsored work. Neither the United States, nor the Commission, nor any person acting on behalf of the Commission:

A. Makes any warranty or representation, expressed or implied, with respect to the accuracy, completeness, or usefulness of the information contained in this report, or that the use of any information, apparatus, method, or process disclosed in this report may not infringe privately owned rights; or

B. Assumes any liabilities with respect to the use of, or for damages resulting from the use of any information, apparatus, method, or process disclosed in this report.

As used in the above, "person acting on behalf of the Commission" includes any employee or contractor of the Commission, or employee of such contractor, to the extent that such employee or con. tractor of the Commission, or employee of such contractor prepares, disseminates, or provides access to, any information pursuant to his employment or contract with the Commission; or his employment with such contractor.

PACIFIC NORTHWEST LABORATORY RICHLAND, WASHINGTON.

operated by

BATTELLE MEMORIAL INSTITUTE

for the

UNITED STATES ATOMIC ENERGY COMMISSION UNDER CONTRACT AT(45-1)-1830 
BNWL -1365

UC-80, Reactor Technology

\section{EFFECTS OF FAST NEUTRON IRRADIATION ON THE PERFORMANCE CHARACTERISTICS OF REACTOR-GRADE THERMOCOUPLES \\ N. C. Hoitink \\ R. C. Weddle}

Control and Instrumentation Department Systems and Electronics Division

and

D. C. Thompson

FFTF Project

June 1970 
BNWL- 1365

Printed in the United States of America Available from

Clearinghouse for Federal Scientific and Technical Information National Bureau of Standards, U.S. Department of Commerce Springfield, Virginia 22151

Price: Printed Copy $\$ 3.00 ;$ Microfiche $\$ 0.65$ 


\section{EFFECTS OF FAST NEUTRON IRRADIATION ON THE PERFORMANCE CHARACTERISTICS OF REACTOR-GRADE THERMOCOUPLES
N. C. Hoitink
R. $\mathrm{C}$
C. Weddle and D.
C. Thompson

\section{ABSTRACT}

Irradiation of 55 Chromel/Alume 1 thermocouples in the EBR-II reactor to a total fast neutron fluence of about $7 \times 10^{21} \mathrm{nvt}$ and subsequent testing provided significant information regarding anticipated performance of such sensors in a fast flux reactor environment. The tested 0.0625-in. diameter, stainless steel sheathed, $M g O$ insulated sensors included both insulated and grounded junction construction. Tests performed before and after irradiation included wire resistance and insulation resistance measurements, emf versus temperature calibration, and time response determination. Test results revealed negligible change in wire resistance and characteristic time constant values; decreases of up to $10^{4}$ ohms in insulation resistance (due in part to seal failure); and changes in emf versus temperature calibration of up to about $1 \%$. 


\section{CONTENTS}

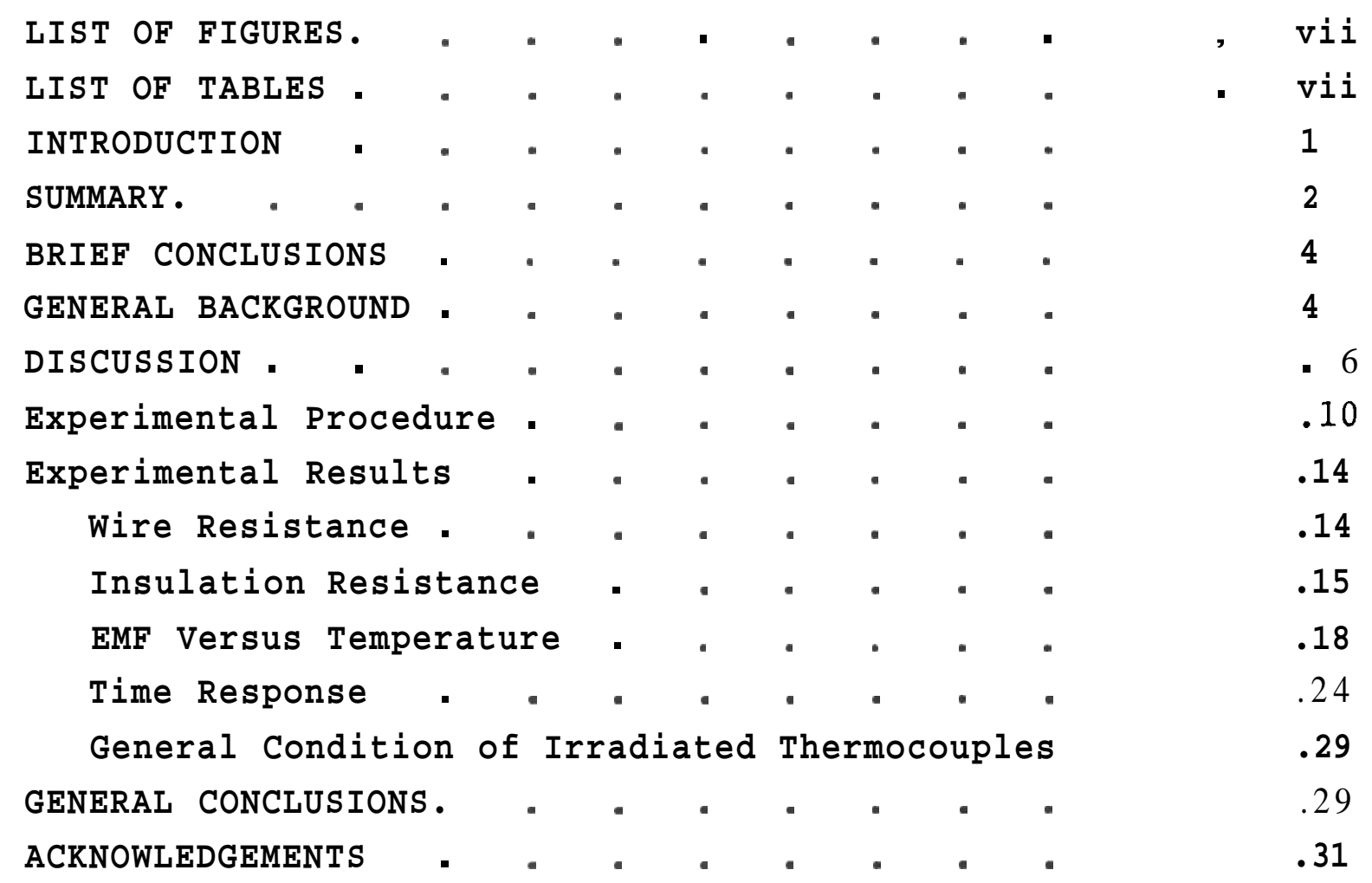




\section{FIGURES}

1 Relations for Thermocouple in a Temperature Gradient 8

2 Positioning Tool and Crimping Block 13

3 Deviation of Average Irradiated (22) and Control (4) Thermocouple Temperatures from Standard 19

4 Pre- and Postirradiation Deviations for Typical Insulated Junction Thermocouple

5 Pre- and Postirradiation Deviations for Typical Grounded Junction Thermocouple

6 Deviations for Typical Control

7 Semilog Response Method for Time Constant Determination

8 Control and Irradiated Thermocouple 1200 to $1000^{\circ} \mathrm{F}$ Time Response

\section{TABLES}

1 Comparison of Pre- and Postirradiation Wire Resistance at $0{ }^{\circ} \mathrm{C}$

2 Pre- and Postirradiation Insulation Resistance Measurements for Insulated Junction Chrome1/Alume1 Thermocouples from Capsules BT-3 and BT-4

3 Insulation Resistance of Cut Thermocouples 17

4 Comparison of Pre- and Postirradiation Time Response 25 


\section{EFFECTS OF FAST NEUTRON IRRADIATION ON THE PERFORMANCE CHARACTERISTICS OF REACTOR-GRADE THERMOCOUPLES
N.
C. Hoitink, R
R. C. Weddle and D.
C. Thompson

\section{INTRODUCTION}

Thermocouples used as coolant temperature sensors in present day nuclear reactors usually employ Chromel/Alume1* wire with compacted magnesia or alumina insulation in an AISI** Type 304 SS sheath. Such devices, if manufactured under correctly controlled conditions with extremely pure materials, usually perform reliably to temperatures of about $1000^{\circ} \mathrm{F}$ and to maximum thermal neutron fluences of about $4 \times 10^{20}$ nvt. (1) However, the liquid sodium cooled Fast Test Reactor (FTR) will require sensors with reliability proven sufficient for operation in a liquid sodium ( $\left.1200^{\circ} \mathrm{F}\right)$ environment for a period of three years. The anticipated environment includes a predicted fast neutron flux density of about $2 \times 10^{13} \mathrm{nv}$ and a gamma level of approximately $10^{8} \mathrm{R} / \mathrm{hr}$. Such severe conditions pose difficult operational problems for the thermocouples.

The initial developmental testing program for the thermocouples focused on determination of effects of fast neutron irradiation on characteristics of 0.0625-in. diameter stainless-steel sheathed, MgO insulated, Chrome1/Alume1 (Cr/Al) sensors. Characteristics examined included calibration drift, wire resistance changes, insulation performance and response time variations--all parameters which could be affected by fast neutron irradiation similar to that expected in the FTR. The EBR-II reactor at NRTS in Idaho served as the test facility. This report presents the initial phase results of the continuing investigation which centers on the

\footnotetext{
* Chromel/AZumeZ - Tradename of the Hoskins Wire Company.

* AISI - American Iron and Steel Institute.
} 
acquisition of pertinent data and on development of various measurement and handling methods appropriate to the program.

The thermocouple irradiation experiments, which included detailed measurements performed both before and after the in-core exposures, encompass one portion of the overall FFTF program related to the required sensors. The end product of the program will be detailed specifications and manufacfacturing requirements necessary to the acquisition of reliable thermocouples. Within the general program, complementary projects at ORNL concentrate on materials evaluation, manufacturing methods and related aspects.

\section{SUMMARY}

The pre- and postirradiation testing of 22 insulated and grounded junction thermocouples, which received an exposure of $7 \times 10^{21}$ nvt in EBR-II, provided useful data regarding possible fast neutron effects on Chromel/Alumel sensors. The experiments also established important techniques for pertinent measurements on irradiated devices and suggested possible areas for additional tests during future examinations.

The evaluation program included wire resistance measurements and time response determinations for a selected number of thermocouples, as well as calibration drift and insulation resistance measurements for all sensors. Four control units (two each of the grounded and insulated junction variety) from the original test sample were not irradiated in EBR-II.

Test res'ults revealed a definite decalibration of the irradiated sensors, but the average temperature deviation from the Pt/Pt-10\% Rh standard remained within 1\%. For the four control sensors, the average deviation did not exceed the $0.375 \%$ tolerance for new wire of this reactor-grade type. A negative deviation from standard values occurred for the irradiated wire during the increasing temperature portion of 
the calibration cycle, but the deviation became positive for the decreasing temperature phase. The explanation for this probably relates to annealing of the damage during portions of the cycle in which the temperature exceeded the recrystallization temperature of the wire.

Time response tests indicated no deterioration in response characteristics of the irradiated sensors but revealed an unexpectedly long time-constant component. Measured 0 to $63 \%$ time-constant values for the irradiated sensors generally agreed to within 0.05 sec with the preirradiation values. The unexpectedly longer component of the time response appeared only in the irradiated units and probably resulted from radiation-induced variations in the Seebeck Coefficient along the wire coincident with the thermal gradient regions of the test apparatus.

Wire resistance variations remained within the $2 \%$ accuracy of the measurement system, as imposed by a 0.5-in. uncertainty of lead wire attachment position. Of the 11 units tested, eight evidenced less than $1 \%$ variation between pre- and postirradiation resistance measurements.

Insulation resistance measurements for the pre- and postirradiation tests evidenced changes by as much as nine decades. Although results in this area appear to be inconclusive, they do suggest seal failure as at least a major part of the cause for decrease in insulation resistance.

The observed general physical condition of the irradiated thermocouples with regard to strength, ductility and appearance did not differ significantly from the control sensors. 


\section{BRIEF CONCLUSIONS}

Results of the test indicate that the EBR-II exposure did cause changes in characteristics of emf versus temperature, but the effects of temperature during irradiation could not be determined from present data.

Wire resistance measurements indicated no change in value within the limits of accuracy and repeatability for the system.

Results of insulation resistance measurements proved inconclusive because of seal failure. The tests should be repeated after the problem of the seal failures has been solved.

More detailed conclusions will be found on page 29 of this report.

\section{GENERAL BACKGROUND.}

To help ensure the acquisition of reliable thermocouples for liquid coolant temperature measurements in the FTR, a legitimate determination of fast neutron irradiation damage must be achieved. Such effects may result in calibration shifts, response time changes, wire resistance changes, or in variations of insulation resistance. Very little information exists regarding the effects of irradiation on nucleargrade thermocouples to fast neutron fluences above $10^{20} \mathrm{nvt}$. As the possibility exists that many of the thermocouples required in the FTR will receive exposures of $10^{22} \mathrm{nvt}$, thorough testing and evaluation must be undertaken to ascertain the type and extent of the damage.

Chrome1/Alume1 thermocouples, having compacted magnesia insulation and AISI Type 304 SS sheaths, appear to be best suited for the FTR application, based on demonstrated performance in thermal reactors. (2-9) Little decalibration of Chrome1 occurs in thermal reactors because of the low thermal 
neutron absorption cross section of its major constituents; nickel, chromium and silicon. (4) Alumel is also primarily nickel with small amounts of manganese, iron, cobalt, copper, aluminum and silicon. The slightly greater decalibration of Alumel probably relates to the conversion of some manganese (relatively high thermal cross section) to iron during reactor irradiation. The radiation-induced errors in the Chromel and Alumel wires appeared, in recent work, (2) to be compensating (rather than additive) in a complete thermocouple. Reports(2) have been issued on Chromel/Alumel thermocouples used up to $5500 \mathrm{hr}$ in the MTR (to neutron fluences of $6 \times 10^{20} \mathrm{nvt}$ fast and $2 \times 10^{21} \mathrm{nvt}$ thermal) with no detectable permanent damage caused by irradiation. Other investigations to equal or lower fluence levels verify these conclusions. $(3,10,11)$

The effects of fast neutron damage have received far less study than have other problem areas. In general, fast neutron damage in metals produces vacancy clusters or dislocations which cause changes in thermal and electrical conductivity, similar to effects derived from cold working the metal. (12) Studies (13) have shown that cold-worked Chrome1/Alumel thermocouples generate smaller output voltages than annealed sensors. This effect, then, indicates the possibility of a reduced output for thermocouples which have received extensive fast neutron exposure. Since such defects tend to anneal out, the temperature environment during both irradiation and subsequent testing bears importantly upon the results.

In addition to fast neutron radiation damage effects, a number of other factors influence the selection of thermocouples for use in the FTR. Response time, reliability, compatibility with the liquid sodium environment, and general ruggedness impose stringent and possibly conflicting requirements. Grounded-junction sensors improve response time but evidence reduced reliability as a result of stress generated 
within the fastened element by different thermal expansion characteristics of the sheath and thermocouple wire. Increased physical size improves reliability, but at the expense of response time. Improved reliability results by matching the temperature coefficient of expansion of the sheath to that of the wire, but limitations occur because few materials are acceptable for immersion in the liquid sodium environment of the FTR. Thus, such factors influence the selection of applicable sensors.

\section{DISCUSSION}

This report describes only the initial experiments designed to obtain preliminary information concerning radiation effects on 0.0625-in. diameter, stainless-steel sheathed, mineral-insulated, Chrome1/Alumel thermocouples irradiated to $7 \times 10^{21}$ nvt. the total program, of which these experiments form a part, considers phases of selection and specification of thermocouples for the FTR and for the Liquid Metal Fast Breeder Reactors Program in general. In addition to the valuable data obtained during the described tests, the developed measuring and handling techniques will greatly facilitate activities for the future comprehensive program.

This first-phase experimental work did not include analysis of thermocouple performance during reactor operation, but focused on determination of the long-term effects of irradiation. Proposed modifications to the EBR-II reactor should provide a facility in the future for actual operational performance tests. Transient exposure effects, as investigated by others, (14) appear to be insignificant at the fast neutron flux levels of interest.

For the experiments and measurements described in this report, the test sample included 55 30-in. long, 0.0625-in. 
diameter, stainless-steel sheathed, Mgo insulated, nucleargrade, Chromel/Alumel thermocouples, with 30 of the grounded junction variety and 25 having insulated junctions. Glass seals were applied to the lead end of the thermocouples following a 2 -hr "bake-out" at $300^{\circ} \mathrm{F}$. This produced insulation resistance values in the order of $10^{12}$ ohms.

Two capsules (BT-3 and BT-4) placed in the EBR-II core position 4E2 for an equivalent period of 47 days at 50 MW were maintained at temperatures representative of those expected in the FTR. Melt wires included with the samples identified temperatures at the hot junction end of the sensors of $1050{ }^{\circ} \mathrm{F}$ and at the lead end of $850{ }^{\circ} \mathrm{F}$. Included flux wires indicated a total neutron exposure of $7 \times 10^{21} \mathrm{nvt}$ at the hot junction end and $6 \times 10^{20} \mathrm{nvt}$ at the lead end.

Before describing the testing procedures and results, thermoelectric properties and measured thermocouple emf as a function of temperature distribution and material properties should be discussed.

The emf developed in a thermocouple is not generated at the junction of two materials, a point often confused in the literature. In fact, the emf results from interaction of the Seebeck Coefficient, a distributed property of the conductor, with a finite temperature gradient. (15-17) As an example, Figure 1, which schematically illustrates a thermocouple made of two materials, describes the temperature distribution and gradient along the conductors and a hypothetical variation in Seebeck Coefficient along the conductors. The emf generated by the total thermocouple equates algebraically to the sum of the areas represented in Figure 1d. In equation form, this becomes, 


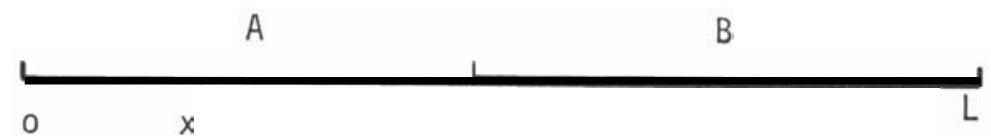

(a) THERMOCOUPLE

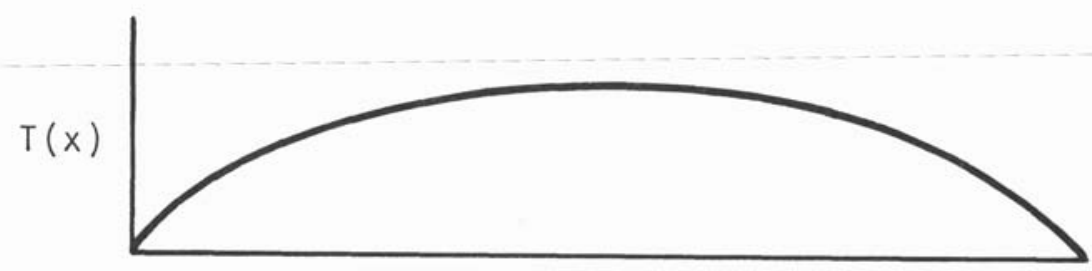

(b) TEMPERATURE DISTRIBUTION

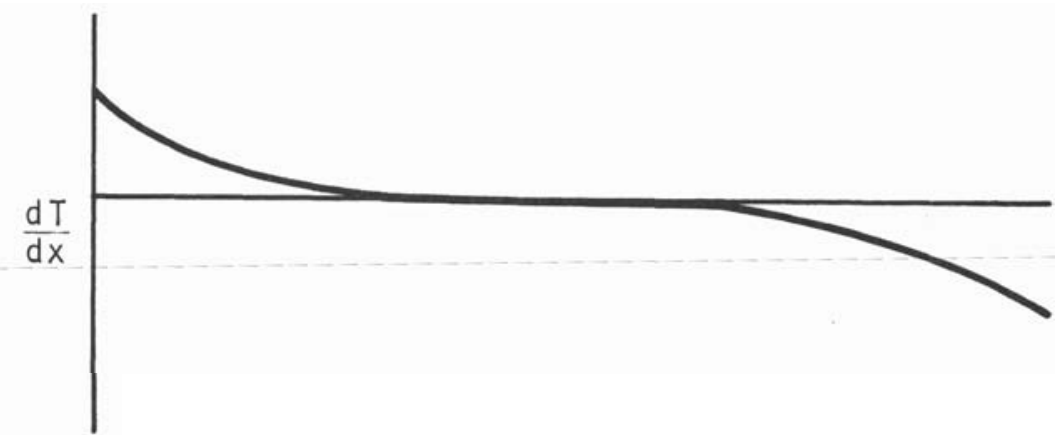

(c) TEMPERATURE GRADIENT

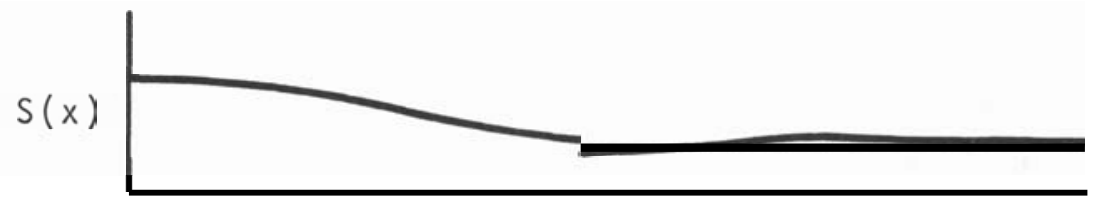

(d) HYPOTHETICAL SEEBECK COEFFICIENT

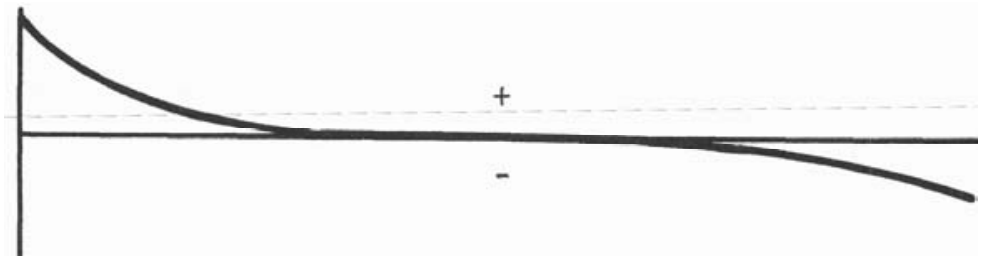

(e) PRODUCT OF (c) AND (d)

FIGURE 1. Relations for Thermocouple in a Temperature Gradient 


$$
E=\int_{0}^{L} S(x)\left(\frac{d T(x)}{d x}\right) d x
$$

where

$$
\begin{aligned}
S(x) & =\text { the relative Seebeck Coefficient at Location } x \\
-\mathrm{dT}(\mathrm{x}) & =\text { the temperature gradient at the Location } x \\
\mathrm{E} & =\text { the total generated thermal emf. }
\end{aligned}
$$

From this equation, several important conclusions can be drawn. Generation of the thermal emf occurs only in regions of finite temperature gradient and not in the normally isothermal regions containing the junction. For homogeneous conductors (no variation in Seebeck Coefficient), assuming the emf to be generated at the junction does not introduce an error. However, inhomogeneity can occur in the conductors: thus, correct interpretation of the thermal emf generation in the temperature gradient regions must be applied with the added possibility of Seebeck Coefficient variation as a function of both temperature and position along the conductors.

The Seebeck Coefficient can be affected by variations in material composition and metallurgical state or by physical forces acting on the material. An excellent report by Fenton (15) describes, in some detail, the important factors in each area; but this report considers only two factors. Compositional changes induced by nuclear transmutation present a possible effect, as do metallurgical changes resulting from dislocations or vacancy clusters caused by fast neutrons. Of these factors, changes in metallurgical state depend heavily upon temperature during irradiation and during postirradiation testing. The dislocations or vacancy clusters caused by fast neutrons should result in effects similar to those produced by cold working. In a like manner, annealing should remove 
most of such effects. However, changes in composition, as caused by transmutation, should be relatively unaffected by annealing.

Since irradiation subjected the sensors to fast and thermal neutron flux gradients and to a temperature gradient along the thermocouple length, variations in Seebeck Coefficient could be expected. The ideal calibration technique would scan the thermocouple length with a short, well-defined temperature gradient. Variation in output emf as a function of position along the sensor could then be correlated with known changes in exposure conditions. The experiments described in this report did not include such a test, but expanded future evaluations will permit further investigation in this area.

\section{EXPERIMENTAL PROCEDURE}

Basically identical procedures were followed for the preand postirradiation measurements. However, several differences did occus and these will be described. Measurements included: wire resistance at $32^{\circ} \mathrm{F}$ for a selected sample, insulation resistance for the insulated junction sensors, calibration accuracy, and response time at elevated temperatures. Except for wire resistance, a 11 measurements included four control thermocouples which were not irradiated. All test equipment received certified calibration* immediately prior to use.

Wire resistance measurements were performed on six insulated and six grounded junction devices, with the entire length of each immersed in an ice bath. Reversal of leads to the General Radio Model 1608-A impedance bridge enabled determination of average values (recorded). Placement of the lead wire connection on the thermocouple limited the accuracy of the measurement system. The exact location of the lead wire attachment for the preirradiation measurementscould not be

* PNL Standards Laboratory. 
determined; thus, placement error during postirradiation measurements could have been 0.5-in., giving a possible error about $1.7 \%$. Future tests will rectify this problem.

Insulation resistance measurements, as performed with a General Radio Model 1644 high megohm bridge, characterized the end seals and MgO insulation resistance. Originally, such tests centered on determination of properties of insulation following irradiation; however, failure of end seals reduced the measured resistance, and this resulted in inconclusive information about the $\mathrm{MgO}$.

Calibration of the sensors for temperature versus emf used a 3-in. diameter, 30-in. long tube furnace to provide temperatures from $200{ }^{\circ} \mathrm{F}$ to $1400{ }^{\circ} \mathrm{F}$ in 200 degree steps. For the preirradiation calibration, groups of eight sensors were placed in an Inconel equalizing block, while a total of 33 sensors received simultaneous postirradiation exposure in a 3 -in. diameter, aluminum-bronze equalizing block. The aluminum-bronze material significantly reduced thermal gradients as compared to those observed in the Inconel block. The sensor bundle, positioned with the hot junctions at the center of the furnace, included a Pt/Pt-10\% Rh standard thermocouple for temperature reference. Welded connections provided lead wire attachment for the preirradiation measurements; however, for the postirradiation tests, half of the sensors used miniature Chrome1/Alume1 plug/jack connectors, while the rest used crimp connectors. A Joseph Kaye Co. Model PRJL24C cold junction reference system provided the $32{ }^{\circ} \mathrm{F}$ reference for the thermocouples for a 11 tests, while a Leeds and Northrup Co. Model K-4 potentiometer measured the output emfs.

Time response measurements included increasing temperatures from 800 to $1000^{\circ} \mathrm{F}$ and decreasing from 1200 to $1000^{\circ} \mathrm{F}$. The thermocouple reached equilibrium at either $800{ }^{\circ} \mathrm{F}$ or $1200{ }^{\circ} \mathrm{F}$ 
in an 18-in. long, vertical tube furnace prior to a gravity drop of about 16 in. into a stirred salt bath of $1000^{\circ} \mathrm{F}$. The thermocouple output emf, as recorded on a Brush Mark 280 strip chart recorder, provided information for calculation of the 0 to $63 \%$ time constant by several acceptable methods. A digital measurement system, as developed to determine the characteristic value for the thermocouple, proved unacceptable for data retrieval because several irregularities appeared in the nominally exponential response. Specifically, all tested grounded junction sensors revealed multiple time-constant response characteristics. Also, a 11 irradiated units (grounded and insulated junction) evidenced a second very long (20 times normal) time component in response. Since an instrument for automatic recording of this characteristic value must have a pure exponential input, such application will give erroneous data for the described situation. In view of this, the method used to record the full response characteristics seems appropriate and safe for future retrieval of pertinent data.

Handling of the irradiated sensors in the hot cell required several special techniques. The candidate sensors used 0.010-in. diameter wire which had to be connected to the 0.020-in. diameter lead wire. A $200 \mathrm{R} / \mathrm{hr}$ gamma level at $1 \mathrm{ft}$ from the bundle of irradiated thermocouples clearly required remote attachment of the lead wires for subsequent testing. The magnetic properties of Alumel proved useful for wire identification, since insertion of the thermocouple lead wire into the air core region of a small inductor connected to an inductance bridge showed a recognizable inductance increase for the Alumel wire. Two methods proved useful and acceptable for lead attachment. Half of the tested group used a crimp connection with the connector spot-welded to the extension lead prior to placement in the hot cell. Figure 2 illustrates the crimping tool and positioning block, as modified for remote 
BNWL- 1365

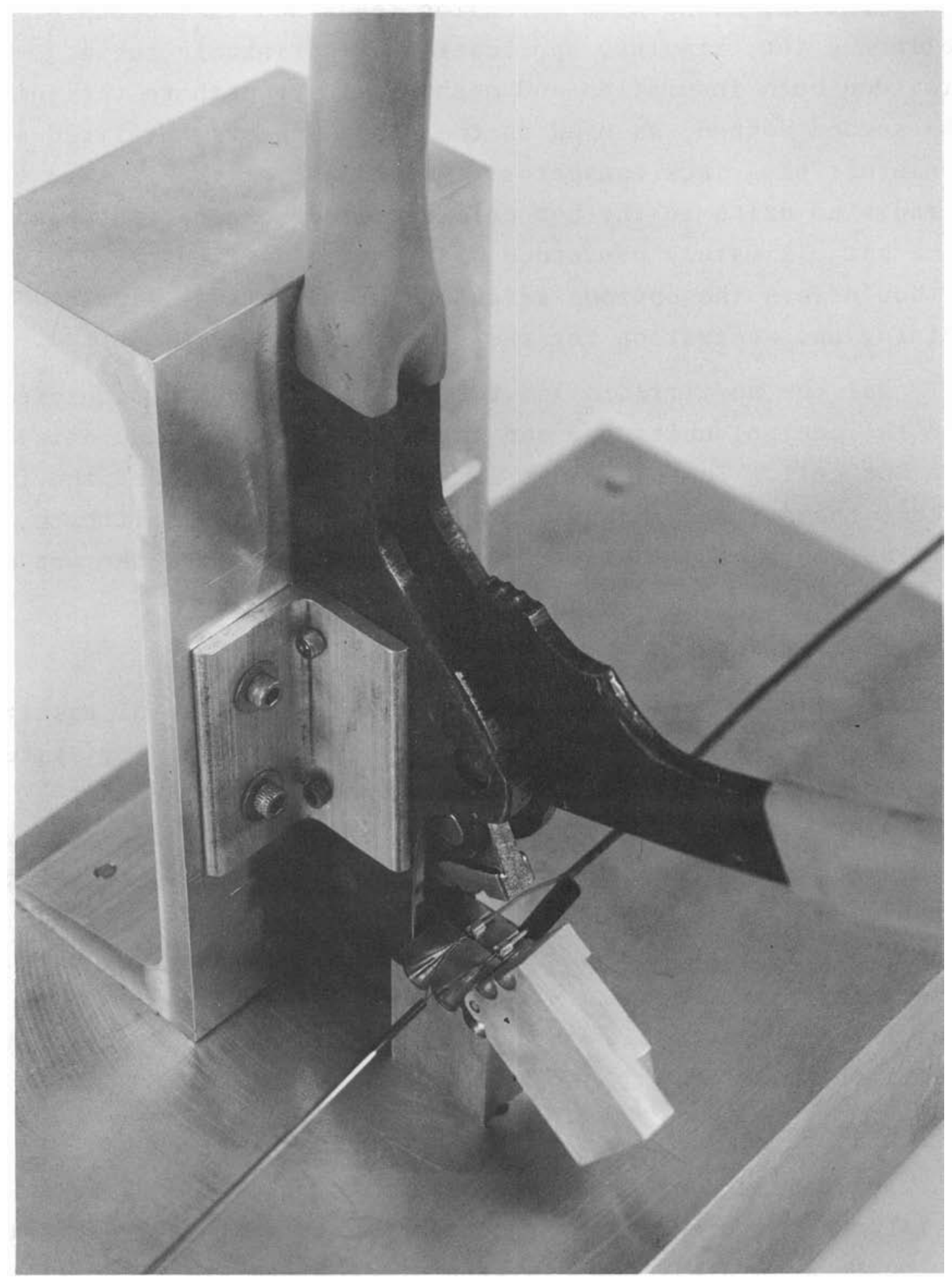

Neg 0693408-3

FIGURE 2. Positioning Tool and Crimping Block 
manipulation, along with extension leads and thermocouple. Following the crimping, application of shrinkable tubing provided both insulation and mechanical strength to the joint. The second method, as used on the other sensors, utilized a miniature plug-jack connector. Attachment of the jack to the irradiated units in the hot cell required some patient practice but ultimately proceeded with little difficulty. This method offers the obvious advantage of permitting simple joining and separation for the sensor and leads.

For the postirradiation tests, a 11 measurement equipment and the control units for the three furnaces remained outside the hot cell. The equipment in the hot cell included the furnaces, the stirring motor and controller for the salt bath, and various small hand tools. Personnel did not enter the not cell, of course.

EXPERIMENTAL RESULTS

The test program produced interesting and useful results and indicated areas for further investigation, and for system refinements. Comparison of pre- and postirradiation data provided performance information for the irradiated sensors. However, other significant results stem from comparison of the irradiated sensors with the nonirradiated controls, since system accuracy can be ensured only through such procedures. Except for wire resistance measurements, comparison of the irradiated thermocouples with the controls provided extremely useful information.

$\underline{\text { Wire Resistance }}$

Table 1 tabulates the pre- and postirradiation wire resistance measurements. As mentioned earlier, the inability to locate accurately the position of preirradiated lead attachment limited reproducibility to within about $1.7 \%$, corresponding to a positioning error of 0.5-in. Irradiation-caused 
resistance changes appear to be negligible within the accuracy and reproducibility limits of the measurement system.

TABLE 1. Comparison of Pre- and Postirradiation Wire Resistance at $0{ }^{\circ} \mathrm{C}$

\begin{tabular}{ccccc}
$\begin{array}{c}\text { Thermocouple } \\
\text { Identification }\end{array}$ & $\begin{array}{c}\text { Preirradiation, } \\
\text { ohms }\end{array}$ & $\begin{array}{c}\text { Postirradiation, } \\
\text { ohms }\end{array}$ & $\begin{array}{c}\text { Change, } \\
\text { ohms }\end{array}$ \\
\cline { 1 - 2 } $\bar{C}$ & 12.35 & & 12.27 & -0.08 \\
$\bar{D}$ & 12.36 & 12.39 & +0.03 \\
$\bar{I}$ & 12.46 & 12.50 & +0.04 \\
$\bar{J}$ & 12.15 & 12.10 & -0.05 \\
$\bar{O}$ & 12.25 & 12.34 & +0.09 \\
$\bar{V}$ & 12.10 & 12.18 & +0.08 \\
$\mathrm{C}$ & 11.84 & Leads & Broke & --- \\
0 & 12.07 & & 12.14 & +0.07 \\
$Q$ & 12.00 & & 12.22 & +0.22 \\
$\mathrm{~S}$ & 11.95 & 12.16 & +0.21 \\
$\mathrm{~T}$ & 11.91 & 12.13 & +0.22 \\
$\mathrm{~W}$ & 11.53 & 11.51 & -0.02
\end{tabular}

Insulation Resistance

Insulation resistance measurements focused on the detection of possible changes in properties of the MgO insulation. To ensure a moisture-tight barrier, glass seals were applied a t PNL prior to shipment of the encapsulated sensors to EBR-II. Care expended during application of the seals, including a final helium leak test, achieved preirradiation insulation resistance values ranging, in most instances, from $10^{11}$ to $10^{13}$ ohms.

Postirradiation measurements produced some interesting results. Table 2 lists the insulation resistance of the insulated junction sensors, as tested at room temperature and with 15 in. of each 30 -in. thermocouple maintained at $1000{ }^{\circ} \mathrm{F}$. 
TABLE 2. Pre- and Postirradiation Insulation Resistance Measurements for Insulated Junction Chromel/Alumel Thermocouples from Capsules BT-3 and BT-4

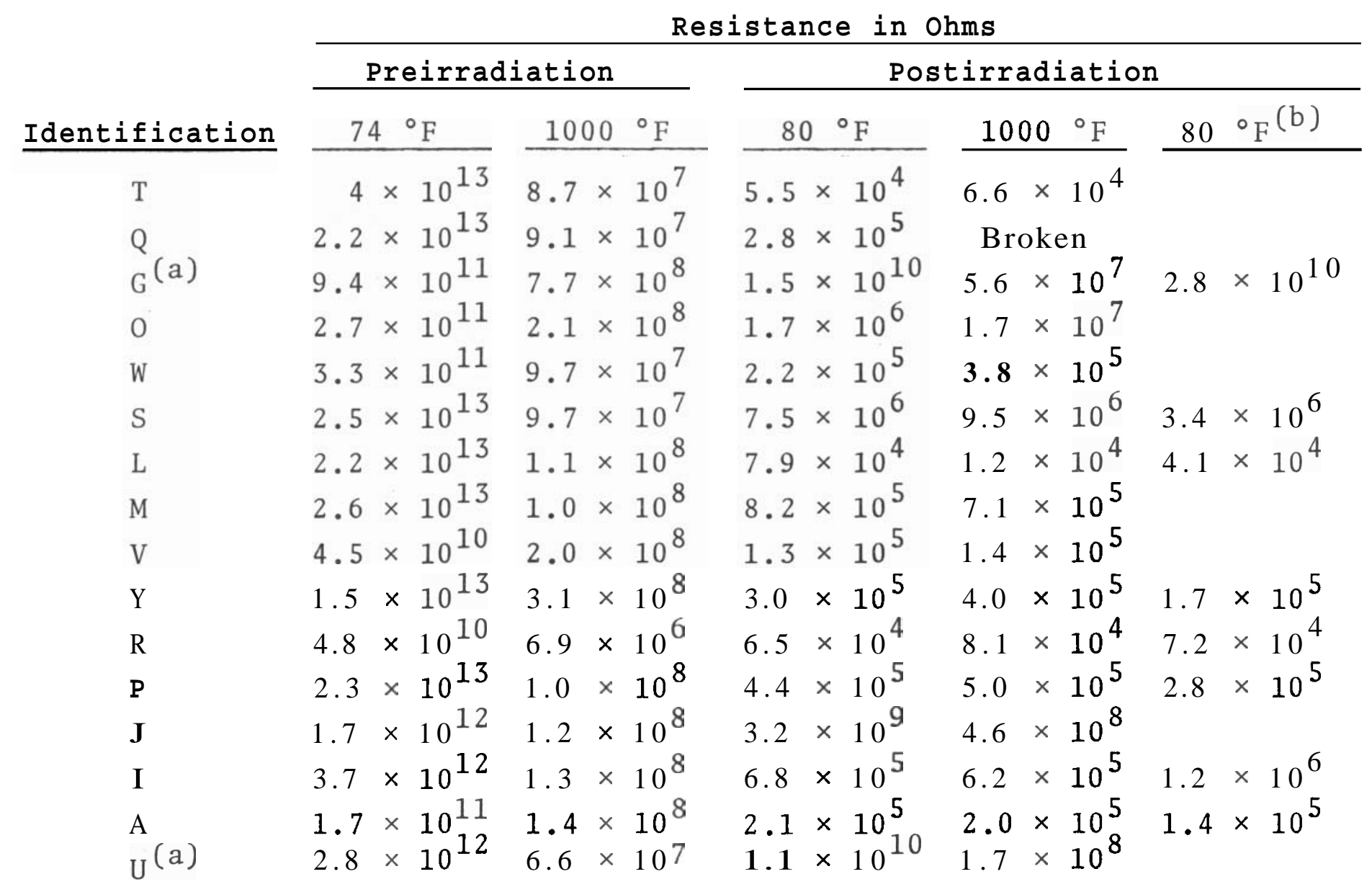

a. Control Thermocouples.

b. These measurements made at room temperature after over-night bake-out with entire thermocoup Ze Zength in furnace. 
In addition, for a selected sample, tests at room temperature followed an over-night "bake-out" at $1000^{\circ} \mathrm{F}$. The irradiated sensors evidenced a decrease in insulation resistance of up to nine decades in some cases, while the two controls maintained resistance within two decades. The overnight "bake-out" did not improve the insulation resistance; however, some moisture could have re-entered the thermocouple during the cooling process. For several sensors, removal of the last inch (includes glass seal) of the thermocouple assembly markedly increased the insulation resistance of the "remainder," as shown in Table 3. The insulation resistance of one sensor increased to $2 \times 10^{10}$ ohms after removal of the seal. Thus, the glass seals apparently account for the low insulation resistance. The seals also showed evidence of extensive embrittlement. Movement of the connection leads, as required for electrical assembly, caused breakage of most glass seals, while similar operations on the control sensors had less apparent effect. Deterioration of the insulation resistance (two decades) of the control thermocouples produced no surprise, as they had been stored (without protection) for two years and had probably accumulated some form of residue. The failure of the glass seals prevented proper determination of stability properties of the MgO insulation.

TABLE 3. Insulation Resistance of Cut Thermocouples

\begin{tabular}{|c|c|c|c|}
\hline \multirow[b]{2}{*}{ Identification } & \multicolumn{3}{|c|}{ Resistance in Ohms } \\
\hline & $\begin{array}{l}\text { Before } \\
\text { Cutting }\end{array}$ & $\begin{array}{c}1-\text { in. } \\
\text { Seal End } \\
\end{array}$ & $\begin{array}{l}\text { Remaining } \\
\text { Thermocouple }\end{array}$ \\
\hline $\mathrm{F}$ & $1.4 \times 10^{6}$ & $1.7 \times 10^{6}$ & $1 \times 10^{7}$ \\
\hline$Q$ & $2.8 \times 10^{5}$ & $8.6 \times 10^{5}$ & $1.3 \times 10^{7}$ \\
\hline $\mathrm{R}$ & $9 \times 10^{4}$ & $2.5 \times 10^{5}$ & $1.2 \times 10^{9}$ \\
\hline L & $2 \times 10^{5}$ & $4.2 \times 10^{5}$ & $2.0 \times 10^{10}$ \\
\hline
\end{tabular}


BNWL -1365

\section{$\underline{\text { EMF Versus Temperature }}$}

The calibration of emf versus temperature included 22 irradiated sensors and four controls, all examined simultaneously. Positioning the controls with one in each quadrant of the equalizing block verified acceptable temperature uniformity. In view of the extensive number of pages needed to present all individual calibration curves, this report presents information about the average temperature deviations along with several representative individual pre- and postirradiation curves.

Figure 3 illustrates the temperature deviation from the Pt/Pt-10\% Rh standard for the average temperature of the $\mathbf{2 2}$ irradiated sensors and for the average temperature of the four control thermocouples. As indicated, performance of the control thermocouples ensured the accuracy of the measurement system. The deviations for the irradiated sensors appear somewhat large, but generally remain less than $1 \%$, as compared with the specification accuracy (for this grade wire) of $0.375 \%$ for new wire. As a point of interest, the value for new wire implies very little (if anything) about the accuracy of thermocouples after a period of use. For the increasing temperature portion of the calibration cycle, the deviations proved generally negative (as the averages show) but become more positive during the decreasing portion of the cycle.

Figures 4 through 6 show pre- and postirradiation deviations from the standard for typical insulated junction, grounded junction and control thermocouples, respectively. The general shape for the individual sensors corresponds very closely to the shape of the average deviation curve. This characteristic held for all tested thermocouples. 


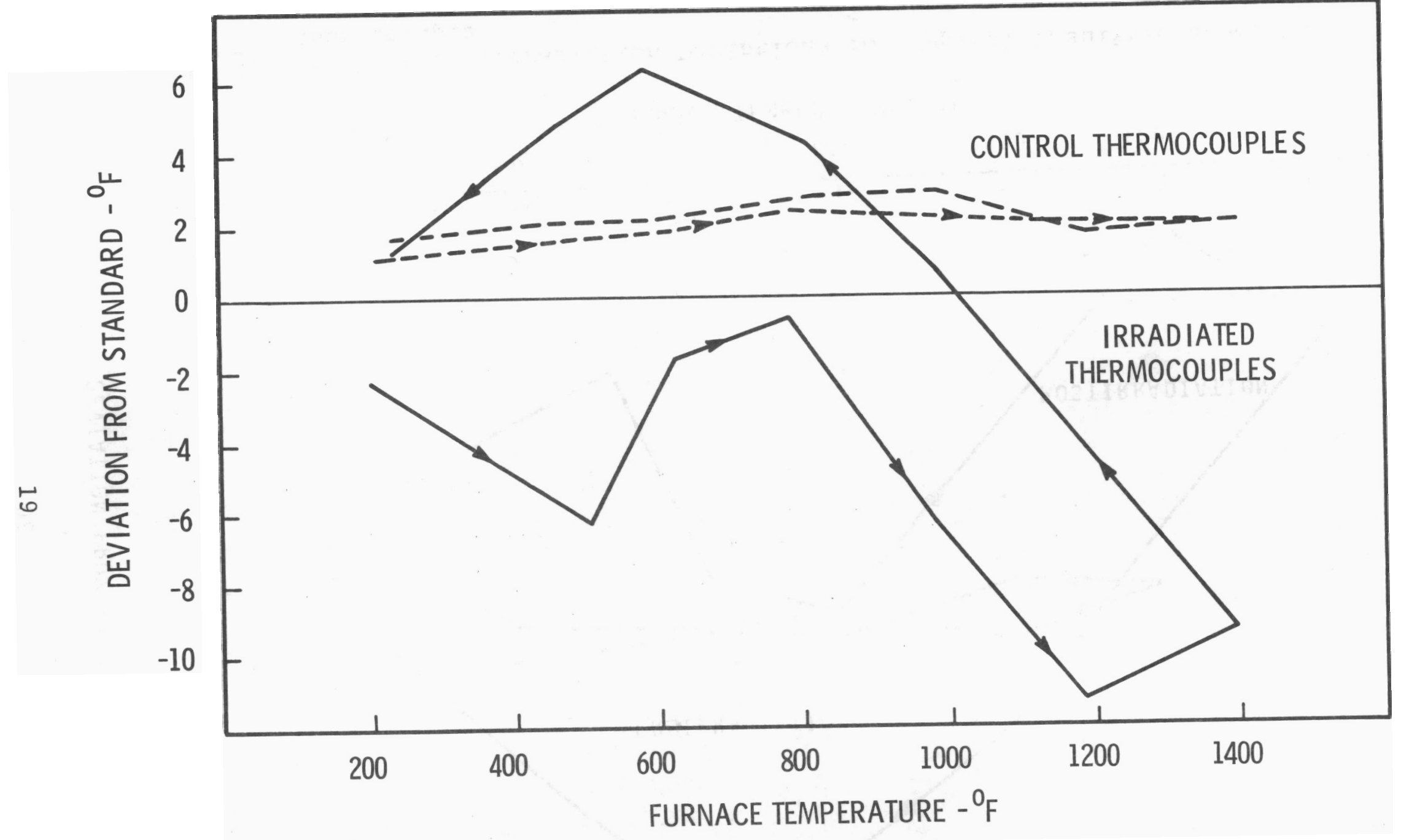

Neg 700034 FIGURE 3

Deviation of Average Irradiated (22) and Control (4) Thermocouple Temperatures from Standard 


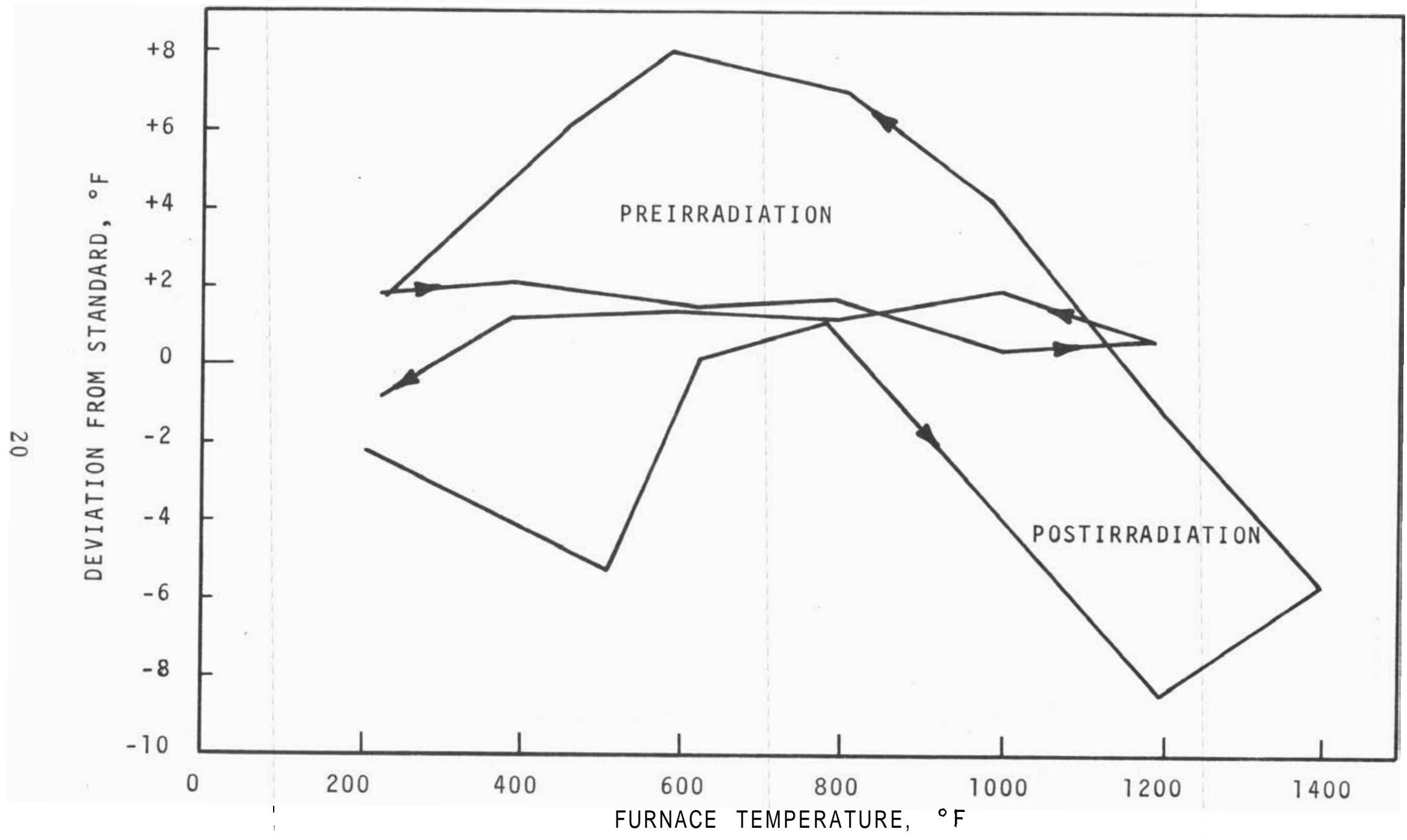

FIGURE 4. Pre- and Postirradiation Deviations for Typical Insulated Junction Thermocouple 


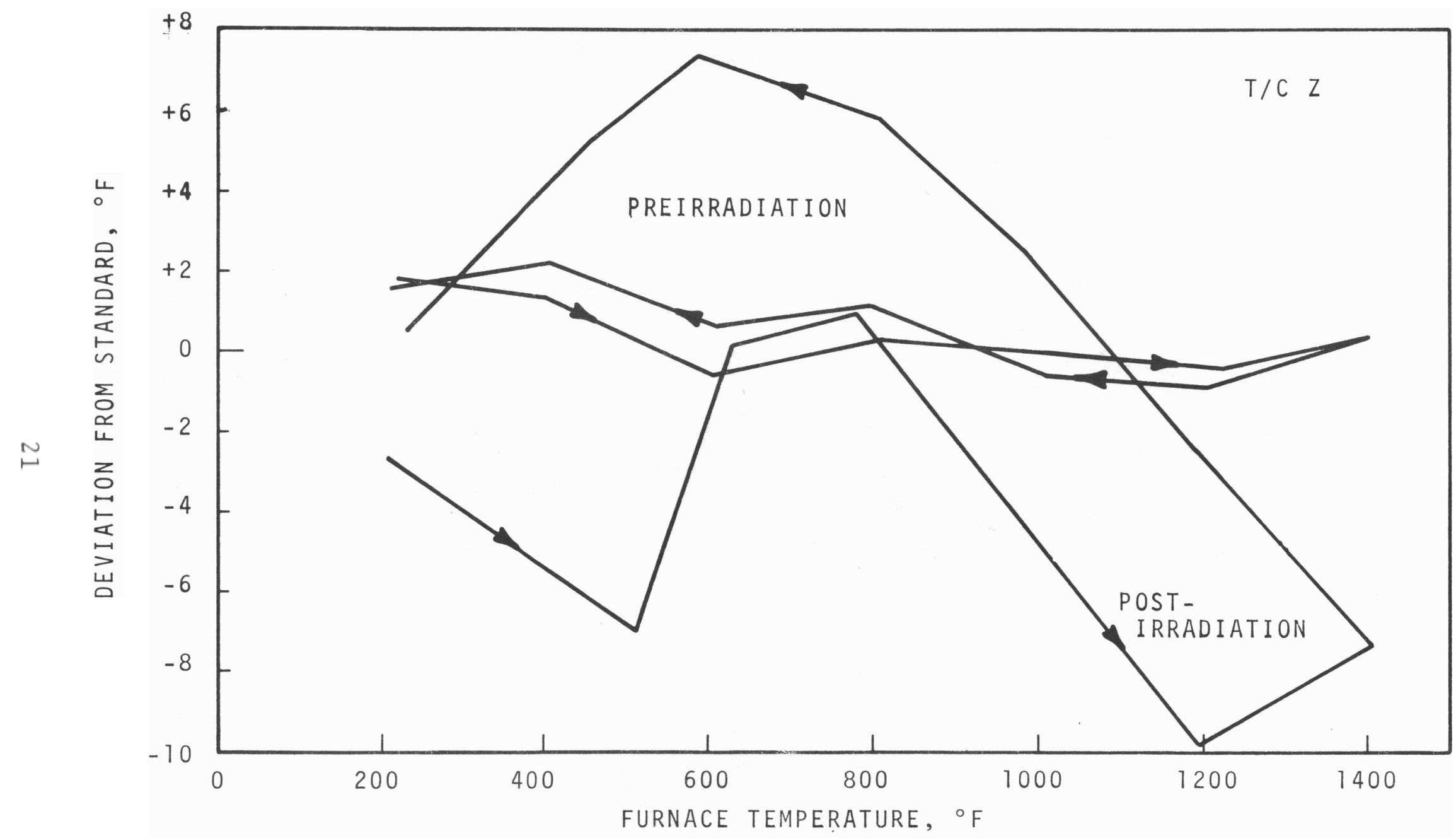

FIGURE 5. Pre- and Postirradiation Deviations for Typical Grounded Junction Thermocouple 


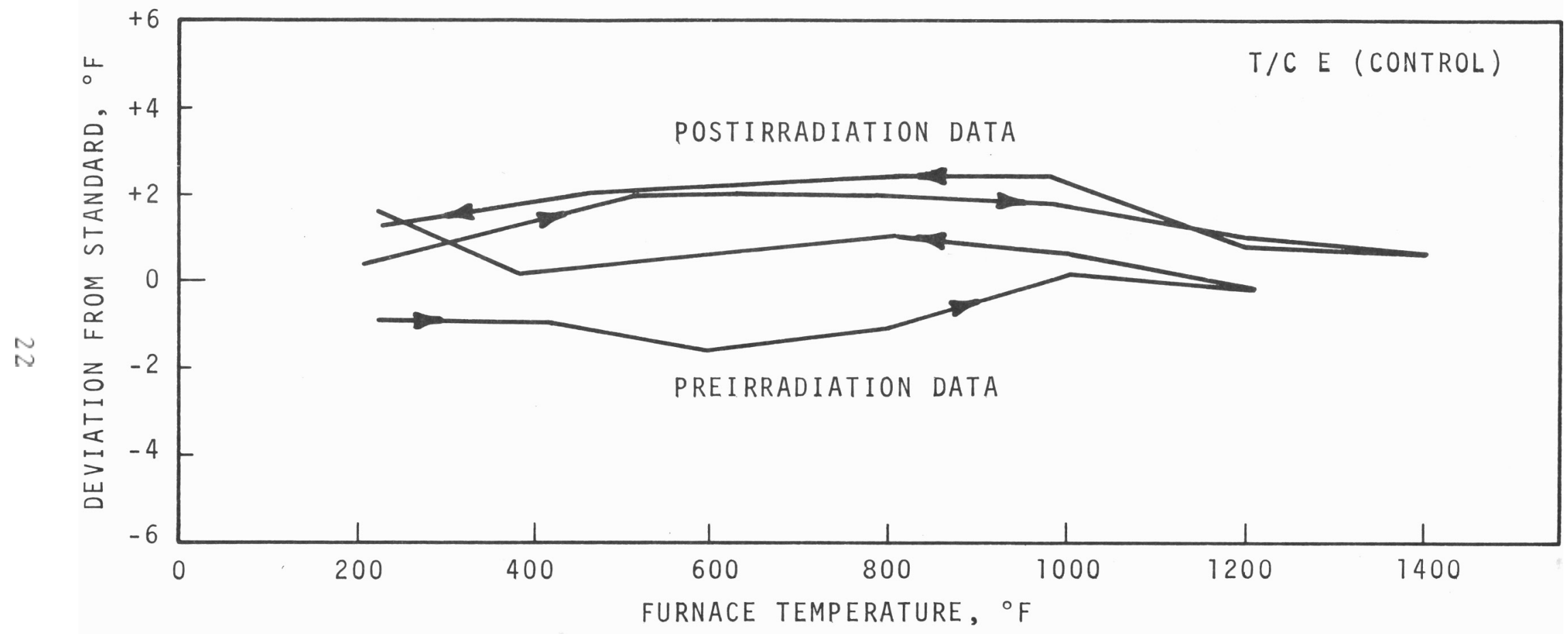

FIGURE 6. Deviations for Typical Control. Data Taken Before and After Irradiation (Control Not Irradiated)*

* The terms "preirradiation" and "postirradiation" simply identify the test series; the control units were not irradiated. 
The negative temperature deviations proved similar to those expected for cold-worked Chromel/Alumel sensors. Since fast neutron damage could be expected to produce changes similar to those caused by cold working, the observed deviations seem reasonable. Quite possibly, the deviations shifted during the decreasing portion of the cycle because the affected regions were annealed at the higher temperatures. The manufacturer states a recrystallization range of 1150 to $1250{ }^{\circ} \mathrm{F}$ for the alloys.

Following completion of the calibration cycle, the thermocouples were returned to $1000^{\circ} \mathrm{F}$. The resulting average deviations corresponded within $0.2^{\circ} \mathrm{F}$ to the top (or decreasing) temperature calibration deviation shown in Figure 3 . The data points marked " $x$ " at $990^{\circ} \mathrm{F}$ on the individual characteristics on Figures 4 through 6 represent the indicated temperature at the return check. This appears to confirm the observation that annealing of the affected regions accounts for the difference between the deviations noted for increasing and decreasing temperatures.

The observed drift in the positive direction of the magnitude indicated in the figures eludes explanation. If the only effect of fast neutron irradiation consisted of the dislocation or vacancy cluster mechanism, annealing should not cause the positive deviation to the magnitude shown. However, other effects which do not anneal out could explain the situation. In particular, transmutation could result in net positive drift following calibration to temperatures which permit annealing of the negative contribution caused by fast neutron damage. For the annealing that occurred during calibration (especially important to tests conducted after the calibration cycles), only a small portion of the thermocouple length, probably less than 10 in., actually reached annealing temperature during the heating cycle; thus, extensive damage could remain. 
The employed testing methods and the relationship of the data to predictable performance of thermocouples in the FTR lead to several pertinent observations. Certainly, the test conditions do not duplicate the anticipated environmental conditions for the reactor application. However, the results do indicate that adequate performance in the reactor, with regard to fast neutron effects, might be anticipated. The emf measured at the thermocouple output stems entirely from portions of the wire existing in a temperature gradient. Thus, an entire irradiated sensor placed in a constant temperature zone would evidence no radiation effects of the measured emf. Clearly then, only the portion of the irradiated thermocouple actually in a temperature gradient contributes to the calibration data. For these tests, a temperature gradient existed from 4 in. back of the hot junction to about 16 in. back. This, then, represents the tested portion of the thermocouple. In the FTR application, much smaller gradients should exist over the part of the sensor which receives the greatest neutron exposure. This should materially reduce the magnitude of the radiation effects on output emf.

\section{$\underline{\text { Time Response }}$}

Time response recordings for the thermocouples provided two important pieces of information. The first relates to comparison of pre- and postirradiation 0 to $63 \%$ time-constant values and the second to the appearance of an unexpectedly long time (15 to $20 \mathrm{sec}$ ) component in the response characteristics of the irradiated units. For discussion, these items will be considered separately; however, the unexpected component has been ignored during calculation of the characteristic time constant.

Table 4 lists the pre- and postirradiation time constants for the insulated junction sensors. The values, as determined from the straight-line plot of response versus time on semilog 
paper, represent the normal 0 to $63 \%$ value for an exponential function. The semilog method of determination, as shown in Figure 7 , provides both the value and an indication of multiple time constant effects (as breaks or shape changes in the otherwise straight-line characteristic). Comparison of the tabulated information indicates generally close agreement for the pre- and postirradiation values. Specifically, 18 out of 24 comparative pairs differ by $50 \mathrm{msec}$ or less while only three differences equal or exceed $100 \mathrm{msec}$. In several cases, a relatively large difference (up to $0.170 \mathrm{sec}$ for "P") exists between two particular values. Although no certain explanation exists, the cause may result from limitations on the graphical measurement accuracy as imposed by significant periodic noise on recordings of the preirradiation time response. Another cause could be variation in stirring speed of the salt bath, or possibly, changes in entrance velocity of the thermocouple into the salt bath.

TABLE 4. Comparison of Pre- and Postirradiation Time Response

Preirradiation Time Constant, sec

Thermocouple $\underline{\text { Identification }}$

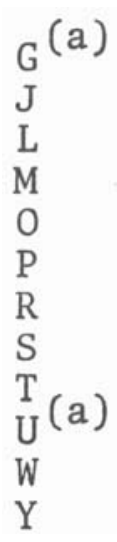

\section{0 to} $1000^{\circ} \mathrm{F}$

0.52

0.67

0.46

0.68

0.47

0.67

0.55

0.97

0.46

0.83

0.55

0.67
1200 to

$1000^{\circ} \mathrm{F}$

0.47

0.70

0.49

0.77

0.45

0.70

0.48

0.95

0.50

0.81

0.55

0.60
Postirradiation Time Constant, sec 800 to 1200 to $\underline{1000^{\circ} \mathrm{F} \quad 1000^{\circ} \mathrm{F}}$

0.51

0.70

0.44

0.64

0.45

0.66

0.48

0.91

0.51

0.85

0.51

0.63
0.46

Leads Broke

0.41

0.66

0.40

0.53

0.44

0.93

0.43

0.81

0.49

0.50

a. Denotes nonirradiated control. 


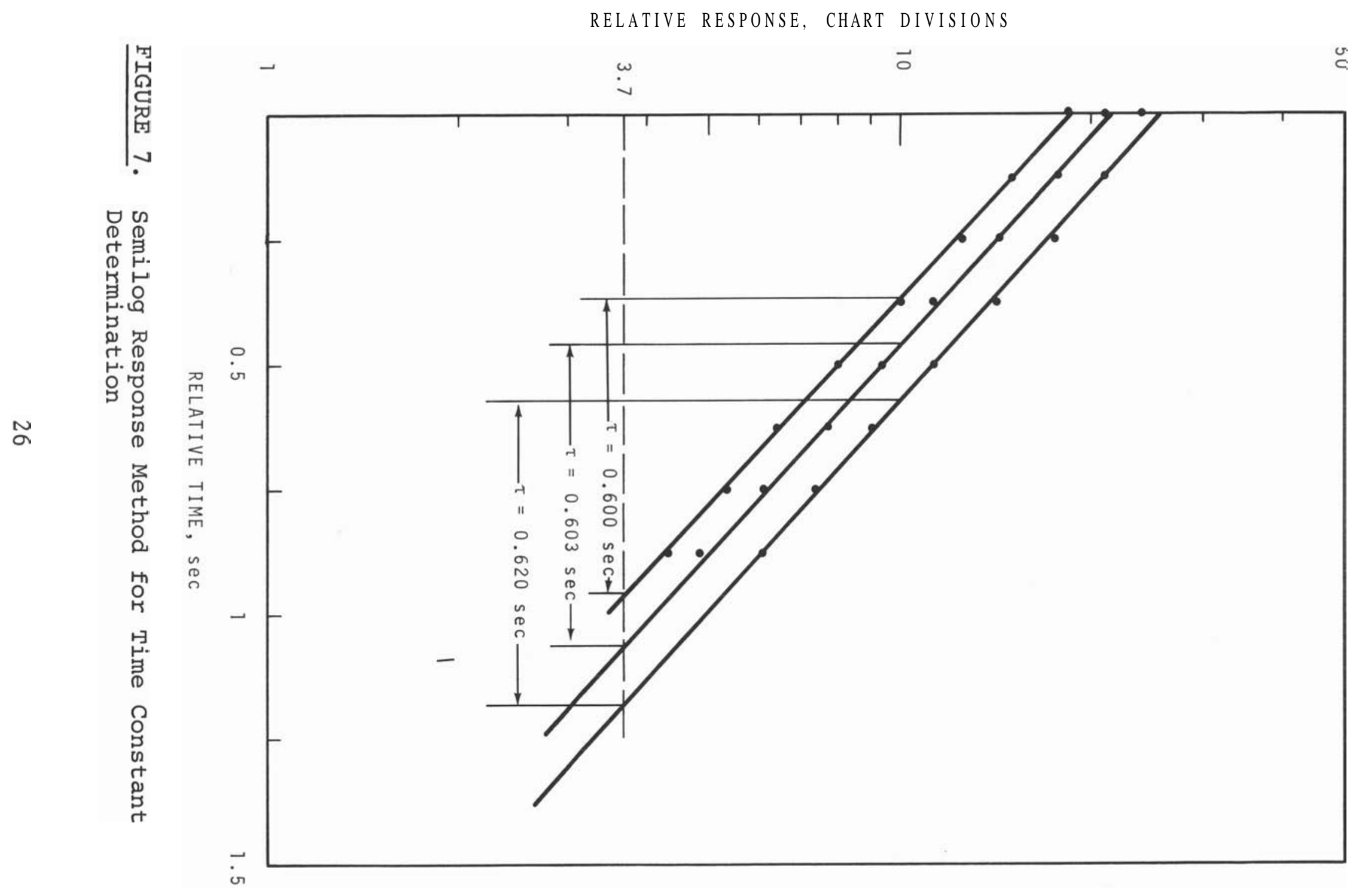

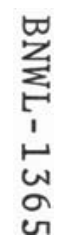


The second interesting result of the time response tests related to the appearance of an unexpected long component in the characteristics of the irradiated units. Figure 8 , a comparison of the time response of a control unit with that of an irradiated sensor, clearly identifies the long component of the irradiated unit on the portion of the chart where speed has been slowed by a factor of 100 . For the shown output, the resulting primary time constant equates to approximately 0.4 sec, but the clearly evident slow component, which responds in the opposite direction, measured about $16 \mathrm{sec}$. For response time measurements for increasing temperature (800 to $\left.1000^{\circ} \mathrm{F}\right)$, the same slow component appeared, and its direction (positive) renained unchanged. As shown in the top curve cf Figure 2, the control units did not evidence the long component. Thus, the effect must relate to changes in the thermocouple produced during irradiation in EBR-II.

A possible explanation can be formulated for the mexpectedly long time-response component. As noted in the calibration tests of emf versus temperature, the irradiated devices produced a lower output than did the nonirradiated sensors. From previous observations, the regions affected to a greater extent produce a smaller output voltage. Since the emf arises from the portion of the thermocouple in a gradient, the final output will be greatest for the condition of application of the largest gradient (room temperature to $1200^{\circ} \mathrm{F}$ ) to the back portion of the sensor. Thus, when the thermocouple drops in the salt bath, the initial emf output responds quickly as the hot junction comes rapidly to temperature, but ultimately, (with the slow heat conduction in the upper tube furnace) the emf must finally correspond to the existing gradients over the complete sensor. This situation would cause the emf to increase as the rear portion of the thermocouple reaches eouilibrium. Although the details of the explanation may be 

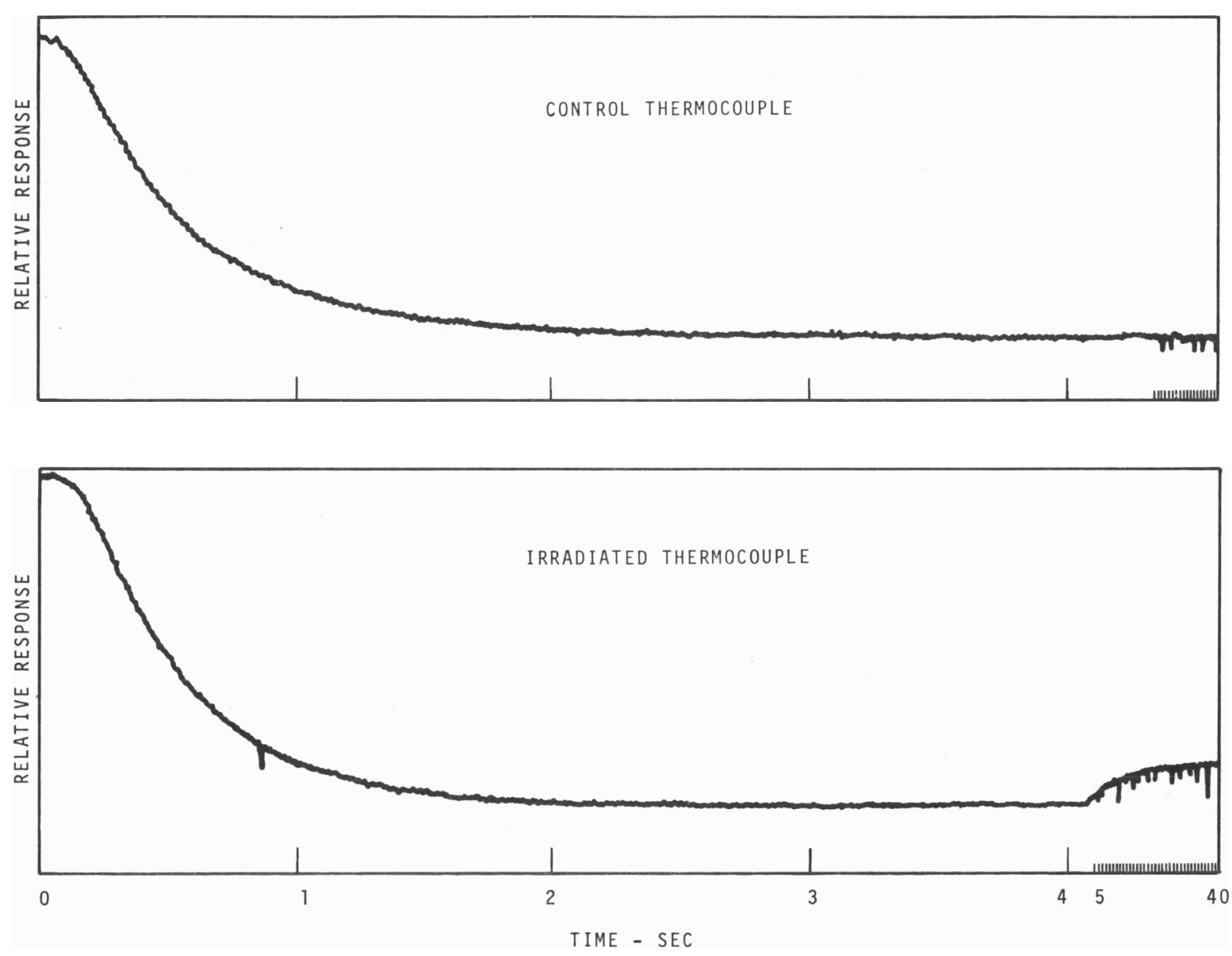

FIGURE 8 Control and Irradiated Thermocouple $1200^{\circ} \mathrm{F}$ to $1000^{\circ} \mathrm{F}$ Time Response. Note Slow Time Constant Component in Irradiated Thermocouple Response. 
questioned, the observed anomaly does result from variations in the Seebeck Coefficient in the temperature gradient regions of the complete thermocouple.

General Condition of Irradiated Thermocouples

As described in the section on insulation resistance, the glass seals evidenced some degree of brittleness after irradiation. However, the appearance of the seal did not change noticeably. The thermocouple lead wire (0.010-in. diameter) remained reasonably ductile and strong, and the extensive bending, straightening, pulling and other inevitable consequences of hot cell operation caused failure of only a few wires. Sheath diameter measurements for three irradiated thermocouples revealed a maximum deviation from the nominal 0.0625-in. of only 0.0015-in. In general, except for the seals, the irradiated sensors appeared to have mechanical characteristics quite similar to those of the nonirradiated devices.

\section{GENERAL CONCLUSIONS}

Although the preceding portion of the report provided a number of conclusions stemming from the results of the measurements, several additional comments appear to be of significance.

The differences noted between pre- and postirradiation data, as well as differences in performance between irradiated and control thermocouples, indicate that the EBR-II exposure did cause changes in characteristics of emf versus temperature. The effects of temperature during irradiation could not be determined from present data, but future tests will include a group of thermocouples for temperature-only exposure similar to that expected for the units in EBR-II. Other tests should definitely include various neutron exposures with different temperatures but funding limitations prevent such plans at this time. In addition, calibration with better defined 
temperature gradients which could be, in essence, moved along the length of the sensor would provide valuable information and could possibly permit correlations of variations of Seebeck Coefficient with neutron exposures along the length of the complete thermocouple.

Wire resistance measurements reported here indicated no change within the limits of accuracy and repeatability for the system. However, references in the literature ${ }^{18}$ suggest a close relationship between conductivity and Seebeck coefficient with the related possibility that changes in wire resistance could be used to predict or confirm variations in thermoelectric properties. Future tests will ensure greater accuracy in an attempt to identify and investigate this relationship.

Results of insulation resistance measurements proved inconclusive because of seal failure. The tests should be repeated during the future program effort but a solution to the seal difficulties has not been achieved at this time and this problem must be solved.

Results of the time response tests suggest that no problem exists for this characteristic. Variation from one sensor to another (fabrication/materials problem) proved much more important than did changes caused by irradiation. Nevertheless, the time response recordings did show strong indications of irradiation-caused variations in the Seebeck Coefficient along the sensor length, as revealed by the unexpected new long component in the response time. This effect appeared to result from the test apparatus which produces several gradient regions along the length of the sensor over which the Seebeck Coefficient varies. A test over the range from room temperature to boiling water, which would result in only one short gradient region, should not produce the observed long time-response component. 


\section{ACKNOWLEDGEMENTS}

The authors express their appreciation to W. G. Spear, N. S. Porter, B. E. Dozer, W. A. Hinckley, K. W. Wood, R. M. Ferdinand, M. R. Wood, J. L. Jackson and M. E. McMahon for their assistance in planning and carrying out this test program.

\section{REFERENCES}

1. M. J. Kelly and W. W. Johnson. Instrumentation and Controls Division Annual Progress Report for Period Ending July 1, 1959, ORNL-2787, pp. 77-79. Oak Ridge National Laboratory, Oak Ridge, Tennessee.

2. W. E. Chapin, J. R. Drennan and D. J. Hamman. The Effect of Nuclear Radiation on Sensors, REIC-43, TIC Report No. 3. Battelle Memorial Institute, Columbus, Ohio, october 31, 1966.

3. High Temperature Thermometry Seminar, TID-7586, Part 1. AEC Division of Technical Information Extension, Oak Ridge, Tennessee. October 1-2, 1959.

4. Temperature: Its Measurement and Control in Science and Industry. edited by C. M. HerzfeZd. Reinhold Publishing Corp. New York, 1962. Vol. 3, part 2. pp. 271-276.

5. High Temperature Thermometry Seminar, WASH-1067. U.S. Atomic Energy Commission, Washington, D. C., p. 299. February 24-26, 1965.

6. Sumposium on Problems in Irradiated Capsule Experiments, edited by W. L. R. Rice, TID-7697. AEC Division of Technical Information Extension, Oak Ridge, Tennessee. October 8-10, 1963.

7. International Symposium on Developments in Irradiation Capsuile Design, edited by D. R. Hoffman, CONF-660511. Available from AEC Division of Technical Information Extension, Oak Ridge, Tennessee, May 3-5, 1966.

8. D. B. Trauger. Experience with Stainless-Steel Sheathed Chromel Alumel Thermocouples in Irradiation Experiments, ORNL-TM-1320. Oak Ridge National Laboratory, Oak Ridge, Tennessee, November 12, 1965. 
9. A. W. Fenton. "Metal-Sheathed Mineral-Insulated Base Metal Thermocouples, "Paper F. 1. International Symposium on In-Pize Irradiation Equipment and Techniques, Cockroft HalZ, AERE, HarwelZ, Berks, England, May 10-12, 1966.

10. F. D. Terry. Effects of Transient Nuclear Radiation on Transducers and Electrical Cables, IDO-16914. Available from AEC Division of Technical Information Extension, Oak Ridge, Tennessee, November 30, 1963.

11. P. E. Madsen. The Calibration of ThermocoupZes Under Irradiation in B.E.P.O., AERE-M-R-649. Atomic Energy Research Establishment, Harwe ZZ, Berks, EngZand, January 1951.

12. G. Friedzander, J. W. Kennedy and J. M. MiZzer. Nuclear and Radiochemistry. John Wiley \& Sons, Inc., New York, 1966.

13. Chromel/AZumel Thermocouple AZlous, Hoskins Mfg. Co., .Catalog M-61 C-A, p. 27. September 1962.

14. G. J. Dau, R. R. Bourassa and S. C. Keeton. "Nuclear Radiation Dose Rate Influence on Thermocouple Calibration," Nuclear Applications, vol. 5. November 1968.

15. A, W. Fenton, R. Dacey and E. J. Evans. Thermocouples: Instabilities of Seebeck Coefficient, TRG-Report-1447(R). United Kingdon Atomic Energy Authority, HarweZl, Berks, Eng Zand, January 1967.

16. W. R. Beam. EZectronies of Solids. MeGraw-HiZZ Book Company, Inc., New York, 1965.

17. Temperature: Its Measurement and Control in science and Industry, edited by C. M. HerzfeZd. Reinhold publishing Corp., New York, 1962. Vol. 3, part 2, pp. 33-38.

18. W. W. Tyler. Electron Theory of Thermoelectric Effects, KAPL-M-WWT-1, Knolzs Atomic Power Laboratory. September 1951. 


\section{$\underline{\text { DISTRIBUTION }}$}

No. of

Copies

OFFSITE

AEC Chicago Patent Group

G. H. Lee

AEC Division of Reactor Development and Technology

Director RDT

Asst Dir for Nuclear Safety

Analysis and Evaluation Br, RDT:NS

Environmental and Sanitary Engrg Br, RDT:NS

Research and Development Br, RDT:NS

Asst Dir for Plant Engrg, RDT

M. J. Prosser

E. Wensinger

A. E. Womack

Facilities Br, RDT: PE

Components Br, RDT:PE

Instrumentation and Control Br, RDT:PE

Liquid Metal Systems Br, RDT:PE

Asst Dir for Program Analysis, RDT

Asst Dir for Project Mgmt, RDT

Liquid Metals Projects Br, RDT:PM

FFTF Project Manager, RDT:PM

Asst Dir for Reactor Engrg, RDT

Control Mechanisms Br, RDT:RE

Core Design Br, RDT:RE

Fuel Engineering $\mathrm{Br}, \mathrm{RDT}: \mathrm{RE}$

Fuel Handling Br, RDT:RE

Reactor Vessels Br, RDT:RE

Asst D i f for Reactor Tech, RDT

Coolant Chemistry Br, RDT:RT (5)

Fuel Recycle Br, RDT:RT

Fuels and Materials Br, RDT:RT

Reactor Physics Br, RDT:RT

Special Technology Br, RDT:RT

Asst Dir for Engrg Standards, RDT

Asst Dir for Nuclear Safety, RDT

215 AEC Division of Technical Information Extension

15 AEC Division of Technical Information Extension

UK/U.S. Fast Reactor Exchange (5)

Euratom/U.S. Fast Reactor Exchange (10) 
No. of

Copies

1

AEC Idaho Operations Office

Nuclear Technology Division

C. W. Bills, Director

1

$\underline{\text { AEC San Francisco Operations Office }}$

Director, Reactor Division

4

AEC Site Representatives

Argonne National Laboratory

Atomics International

General Electric Co., Sunnyvale

Westinghouse Electric Corporation

8

Argonne National Laboratory

H. A. Bryant

R. A. Jaros s

J. M. Harrer

A. L. Hirsch

LMFBR Program Office

J . Mech

G. F. Popper

N. J. Swans on

2

Argonne National Laboratory

Idaho Falls, Idaho

D. W. C is se 1

K. J. Moriarty

5

Babcock and Wilcox Company

Atomic Energy Division

S. H. Esleeck

G. B. Garton

$5 \quad$ Bechtel Corporation

J . J Teachnor 
No. of

Copies

$\perp$

1

1

5

2

1

1 $\underline{\text { BNW Representative }}$

R. M. Fleischman (ZPPR)

Combustion Engineering 1000 MWe Follow-On Study

W. P. Staker, Project Manager

Combustion Engineering

911 West Main Street

Chattanooga, TA 37401

Mrs. Nell Holder, Librarian

General Electric Co.

Advanced Products Operation

Karl Cohen (3)

E. Zebroski

Nuclear Systems Program

$W$. Baxter

General Electric Co. Sunnyvale BRDO Group

L. R. Boyd

Gulf General Atomic Inc. General Atomic Division

D. Coburn

Idaho Nuclear Corporation

J . A. Buckham

Liquid Metal Engineering Center

Canoga Park, California

R. W. Dickinson

$\underline{\text { Liauid Metal Information Center }}$

A. E. Miller

$\underline{\text { Los Alamos Scientific Laboratory }}$

R. D. Baker

J. Biery

D. B. Hall 
No. of

Copies

4

1

1

10

Westinghouse Electric Corp.

Atomic Power Division

Advanced Reactor Systems

D. C. Spencer

\section{ONSITE-HANFORD}

1

2 $\underline{\text { AEC Chicago Patent Group }}$

R. K. Sharp (Richland)

AEC Richland Operations Office FFTF Program

J. M. Shivley

Atlantic Richfield Hanford Company

H. P. Shaw

R. E. Tomlinson

$\underline{\text { Battelle Memorial Institute }}$

Bechtel Corporation

M. O. Rothwell

Douglas United Nuclear Corporation

C. W. Kuhlman

$\underline{\text { RDT Assistant Director for Pacific Northwest Programs }}$ 
No. of

$\underline{\text { Copies }}$

Westinghouse Electric Corp.

J . D. Herb

Battelle-Northwest

W. G. Albert

G. B. Barton

J. M. Batch

A. L. Bement

T. R. B ille te r

D. P. Brown

W. L. Bunch

J. R. Carrel1

W. L. Chase

T. T. Claudson

J. C. Cochran

R. R. Cone

W. Dalos

G. J. Dau

D. R. de Halas

B. E. Dozer

G. E. Driver

J. F. Erben

E. A. Evans

L. M. Finch

L. E. Fort

R. L. Gordon

K. M. Harmon

J . W. Helm

W. A. Hinckley

P. L. Hofmann

N. C. Hoitink

C. N. Jackson

J. L. Jackson

B. M. Johnson

V. P. Kelly

J. J. Leitz

D. H. Lester
W. B. McDonald

J. S. McMahon

R. E. Nightingale

L. T. Pederson

N. S. Porter

J. J . Rasmussen

W. E. Roake

R. R. Schemmel

D. W. Shannon

D. E. Simpson

C. R. F. Smith

W. G. Spear (5)

R. J . Squires

J. L. Stringer

C. D. Swanson

D. C. Thompson

J. C. Tobin

J. W. Upton

R. C. Weddle

N. G. Wittenbrock

B. Wolfe

M. R. Wood

F. W. Woodfield

FFTF File (10)

FFTF TPO

Legal - 703 Building

Legal - ROB, 221-A

Technical

Information (5)

Technical

$\mathrm{Publications}$ 